\title{
Sustainability Handling Slum Settlements in Makassar City, South Sulawesi Indonesia
}

\author{
Batara Surya $^{1}$, Emil Salim Rasyidi ${ }^{1}$, Muhammad Idris ${ }^{2}$ \\ *E-mail: batara.surya@universitasbosowa.ac.id \\ ${ }^{1}$ Department of Urban and Regional Planning, Faculty of Engineering, Bosowa University, Indonesia. \\ ${ }^{2}$ Department of Economic Management, Bosowa University, Indonesia
}

Diterima: 01 Juni 2021 / Disetujui: 02 Agustus 2021

\begin{abstract}
.
This study aims to (1) analyze the spatial integration of work as a determinant of the sustainability of the handling of slums in Makassar City; (2) analyze the direct and indirect effects of handling infrastructure, controlling environmental pollution, and socio-economic empowerment on improving the quality of slums and the sustainability of handling the slums of Makassar City. The research approach used is a sequential explanatory design, which is a combination of quantitative and qualitative research. Data obtained through observation, surveys, in-depth interviews, and documentation. The results showed that the acceleration of Makassar City development towards urban spatial integration had an impact on slum areas that developed at riverbanks and coastal areas. The results of the path analysis show that infrastructure has a direct effect on improving environmental quality by $12.46 \%$, the direct effect of environmental pollution control on improving environmental quality by $10.69 \%$, and the direct effect of socio-economic empowerment on handling slum settlements by $6.76 \%$. Furthermore, the increase in $Y$ was $63.58 \%$ and the effect of $Y$ on $Z$ was $67.57 \%$. The direction of handling the Makassar City slums in the future is oriented to sustainable development including, improving the quality of infrastructure, increasing the productivity of economic ventures, increasing the capacity of government and community institutions in dealing with social problems, social conflicts, towards the creation of social cohesion, fulfillment of livable facilities that are livable and socially just.
\end{abstract}

Key Wor: Slums Settlement, Spatial Integration, Socio-Economic, Environmental Degradation, Sustainable Development

(c) ()

\section{A. INTRODUCTION}

Excess urbanization for the case of large cities and metropolitan areas in Indonesia has a significant influence on increasing population, economic, social, environmental quality degradation, and the development of slums. Urbanization is a very complex phenomenon and its scope is very broad, covering social, economic, political, and geographic aspects (Surya, B, et al., 2020). Urbanization has quite complex impacts on economic inequality, the formation of social territory structures, and the complexity of the urban environment. Urbanization is a worldwide megatrend that has drastically changed people-environment interactions in the last decades and is expected to remain one of the main drivers of global change in the future (Buchecker, M and Frick, J, 2020). Furthermore, capital accumulation in the main city which dominantly tends to lean 
on the economic growth triggers overurbanization, maximum compaction, and land use change (Surya, B, et al., 2020). Thus, urban urbanization is in line with an increase in population, poverty, a decrease in environmental quality, and the development of slums. A major challenge for sustainable urbanization policies and strategies is how to address the complexity of urbanization, especially the ongoing growth of informal settlements and slums in developing countries (Jone, P, 2017).

Makassar City is one of metropolitan cities in Indonesia, functioned as the capitol of Province South Sulawesi and national strategic area. For a periode of five years, the development of population in the Makassar City in average increases of 1,449,065 people (Bappeda of Makassar City, 2019). The increasing population continues to grow in line with the accelerated development of the Makassar City towards economic growth. It was reported four tipological urban growth patterns encompassing low growth, high growth characterized by fragmented development, expansive-growth, and frantic growth cities with remarkable rates of land covering changes at high population densities (Wilson and Wilson,
2016). The growth of cities leads a lot of problems like environmental degradation, traffic congestion, poverty, urban crime, and other social conflicts (Sui, D.Z, et al., 2001; Wilonoyudho, S, et al., 2017). Economy growth of the Makassar City positively correlated with the big scaled, settlement development, space structure changes, space pattern, environmental degradation, and sufficiently complex social issues (Surya, B, et al., 2018).

The acceleration of development of the Makassar City has a direct relation to the economy globalization in the level of area macro. Urbanization has become the determinant factor for spatial integration in the direction of social area structure formation. Such process was signed by the change of space utilization, poverty, and spatial segregation (Surya, 2016; Kovacs, A.D, 2017). While cities atop the global hierarchy of the world's urban places attract wealth, glamour, and prestige, they are also said to be socially polarized to a greater degree than other cities and to attract international migrants disproportionately (Timberlake, M, et al., 2014). The change in space utilization which is very intensive causes the quality of the environment to decrease and the people's lifestyle to change (Sadorsky, P, 2014; Surya, 2016; Peng, J, et al., 2017; 
Wang, H, et al., 2017). The excess of urbanization caused by the involution of the Makassar City affects the increase of spatial needs for various activities such as housing, work, clan, leisure, and facilities (Mc. Gee, 1971; Todaro, 2011; Surya, B, et al., 2018).

The phenomenon of the development of the Makassar City is characterized by the existence of a poor population reaching 50,969 people (i,e., $34.36 \%$ ) of the total population and the existence of 729 hectares of slums (Bappeda of Makassar City, 2018). Spatial integration and the development of formal and informal settlement are influenced by factor: (1) the hierarchy, bond, and linkage system among community or social organization located in a spread structure of community; (2) transformation of spatial structure, organization, behaviour, social-economy institution, and culture related to the productivity of urban economy, and (3) improvement of administration system in terms of government's alignment, through economy collaboration between central, and local government as well as private sector in terms of funding the settlement sector. Economic coalitions are expected to form between a local government and developers, and political coalitions are expected to exist between the central and local governments (Zhang, S, 2014).

Slum settlements that develop in the Makassar City based on their location are divided into four categories, namely (i) slum settlements located in the city center, (ii) slum settlements located in riverbanks and coastal areas, (iii) slum settlements located in activities economy, and (iv) slums located on the periphery. Various programs have been carried out by the government but in its implementation, it has not been able to overcome and deal with the existing problem of slums. In the period 20102017, slum settlements in the Makassar City were recorded at 103 locations, then an increase of 127 locations in 20182019. This figure shows that slums in the Makassar City for 10 years have increased by 24 location and spread across 15 subdistricts. The confirmation results illustrate that excessive urbanization and maximum compacting have an impact on the addition of slum locations due to the inability of the poor to access urban land.

Industrialization and economic growth in the Makassar City have an impact on the conversion of land use and changes in spatial use towards urban spatial integration. Thus, the focus of this study is aimed at answering research 
questions, namely (1) how spatial integration works as a determinant of the sustainability of handling slums in the Makassar City; (2) how the direct and indirect effects of handling infrastructure, controlling environmental pollution, and socio-economic empowerment on improving the quality of slums and the sustainability of handling slums in the Makassar City.

\section{Conceptual Framework Spatial}

\section{Integration and Slum Settlement}

The concept of handling slums is basically aimed at meeting SDGs targets and objectives, namely (1) ending and reducing poverty; (2) reducing inequality; and (3) protecting the environment. The evolution of the concept of poverty shows that the environment has a proportion of increasing poverty awareness (Nahui, Z, et al., 2014). Factors influencing the development of slums in the Makassar City are: (1) excess urbanization; (2) access to socio-economic inequality; (3) inability of people to meet decent housing facilities due to poverty; (4) infrastructure service gaps related to accessibility, flooding urban areas, distribution of clean water services, electricity services, and environmental sanitation of settlements; and (5) behavior of urban communities in relation to the decline in the quality of settlement environments. Slums in poor countries and define the built environment as access to four main basic services: (1) water, (2) electricity, (3) sanitation facilities and (4) type and/or quality of housing (Burns, P.A and Snow, R.C, 2012). The conceptual framework of this study in Figure 1, as follows.

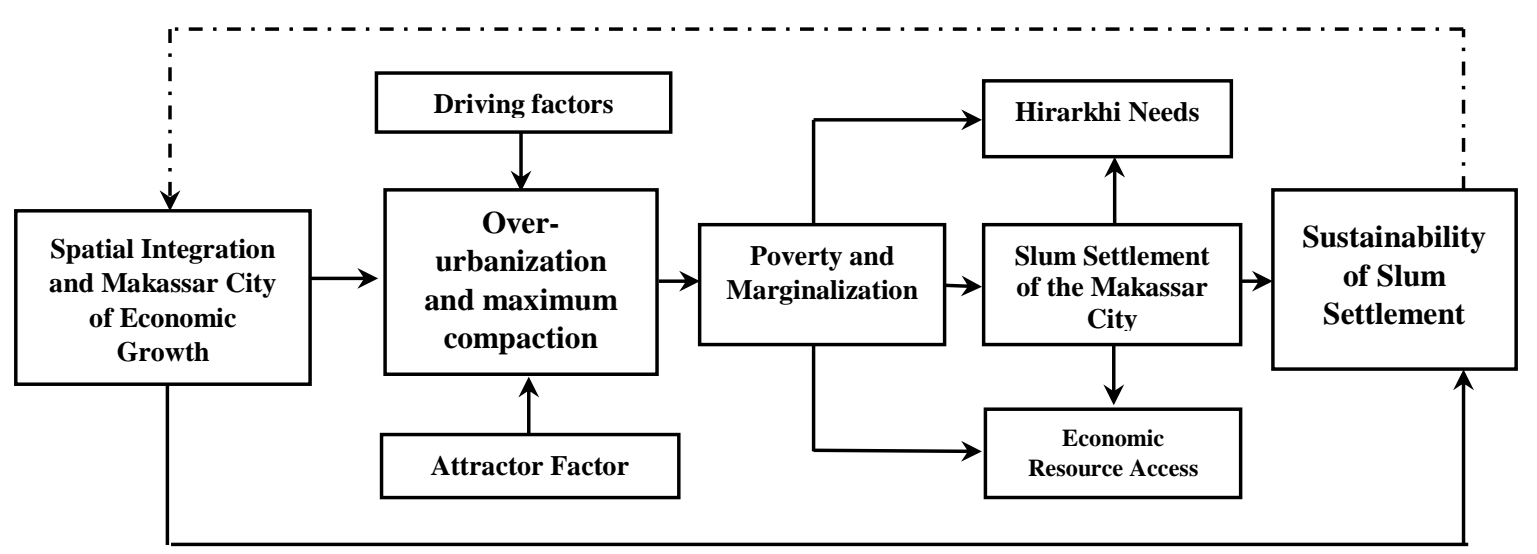

Fig. 1. Conceptual framework for Slum settlement in the Makassar City

The development dynamics of the intensive the driving force of urbanization Makassar City in the direction of and migration of rural populations.Thus, economic growth have become a very with rising overall population and 
urbanization, the pattern of land use and landscape have been altered and such has led to series urbanization-oriented environmental challenges (Arsanjani, J.J, et al., 2013). Excessive urbanization and maximum compaction have an impact on the conversion of land use and conversion of productive agricultural land to the complexity of ecosystems. The concentration of people in cities promotes negative aspects associated with poverty, traffic problems and environmental degradation (Vokoun, M, et al., 2006), and city development imposes qualitative changes focused on strengthening economic, administrative, and culturalsocial functions (Izakovǐcová, Z, et al., 2017). Furthermore, increasing population growth is positively associated with increasing numbers of urban poor in the direction of community marginalization. Poverty and marginalization of the community become the determining factors for the development of slums in the Makassar City. Understanding major external systems' barriers to sustainability for the low- and no-income-level, marginalized communities helps to better understand the importance of integrating social sustainability with economic and environmental sustainability (Adams, M, et al., 2019). Thus, the development orientation that tends towards industrialization and the dominant function of economic activities has an impact on socio-economic inequality, poverty, environmental degradation, and slums. Inequality, in any form and dimension, is a major damaging factor for sustainable development (Kaya, A and Koc, M, 2019).

\section{B. METHODOLOGY}

\section{Approach to Case Study and Research Methods}

The emphasis of this study is oriented to the understanding that the industrialization and economic growth of the Makassar City towards urban spatial integration have an impact on increasing the population of the poor, marginalization, and the development of slums. Thus, this study is directed at analyzing the spatial integration of work as a determinant of the sustainability of slum settlement management. This research is naturalistic, rationalistic, holistic, cultural, and phenomenology (Densin and Lincon, 2009; Creswell, 2016; Sugiono, 2016). The research method chosen was sequential explanatory design by combining quantitative-qualitative approach consecutively. The first stage of the study was conducted using qualitative methods and in the second stage was carried out 
using quantitative methods. The philosophy reasons of combining those two approaches, are (a) triangulation logic; in this case the qualitative research result would be rechecked on the quantitative approach and vice versa, the objective is to enhance the finding results, (b) quantitative and qualitative research were combined to provide the general description, (c) quantitative research was used by social live structural, while qualitative research directs more on the quality of the subject as the turning point, so that both approaches was called for together in the study implementation.

The philosophical reason for combining qualitative and quantitative approaches, namely (1) the logic of triangulation, in this case the results of qualitative research are rechecked in quantitative studies and vice versa, the aim is to strengthen the validity of the findings; (2) quantitative and qualitative research combined to provide a general picture; (3) quantitative research is used on the structural characteristics of social life and qualitative research takes the quality of the subject as a starting point; (4) quantitative approaches are used in analyzing relationships between changes, while qualitative approaches are used to help align the factors that underlie relationships that are built; (5) quantitative approaches are used to uncover structural characteristics of largescale social life, whereas qualitative approaches tend to touch small-scale behavioral, so that when researchers try to uncover both levels, then guides to quantitative and qualitative approaches are used; and (6) to obtain data from two different realities, it is necessary to combine quantitative and qualitative approaches.

\section{Studi Area}

Makassar City, as the capital of the province located in the western coast of Sulawesi. The location and position of the Makassar City is geographically located at the coordinates of $119^{\circ} 18^{\prime} 27.97$ "119 32'31.03" east longitude and $5^{\circ}$ $00 ' 30.18$ " $-5^{\circ} 14^{\prime} 6.49$ " south latitude with total area of $175.77 \mathrm{Km}^{2}$. Furthermore, this research was conducted at 127 slum locations distributed in 15 sub-districts. The selection of research location was based on the consideration: (a) complex issues of slum settlement, (b) the existence of slum settlement which located in strategically functional area, and (c) the effort in handling slum settlement needs a cross sectoral approach. Distribution of slums in the 
Makassar City based on districts in the following Figure 2.

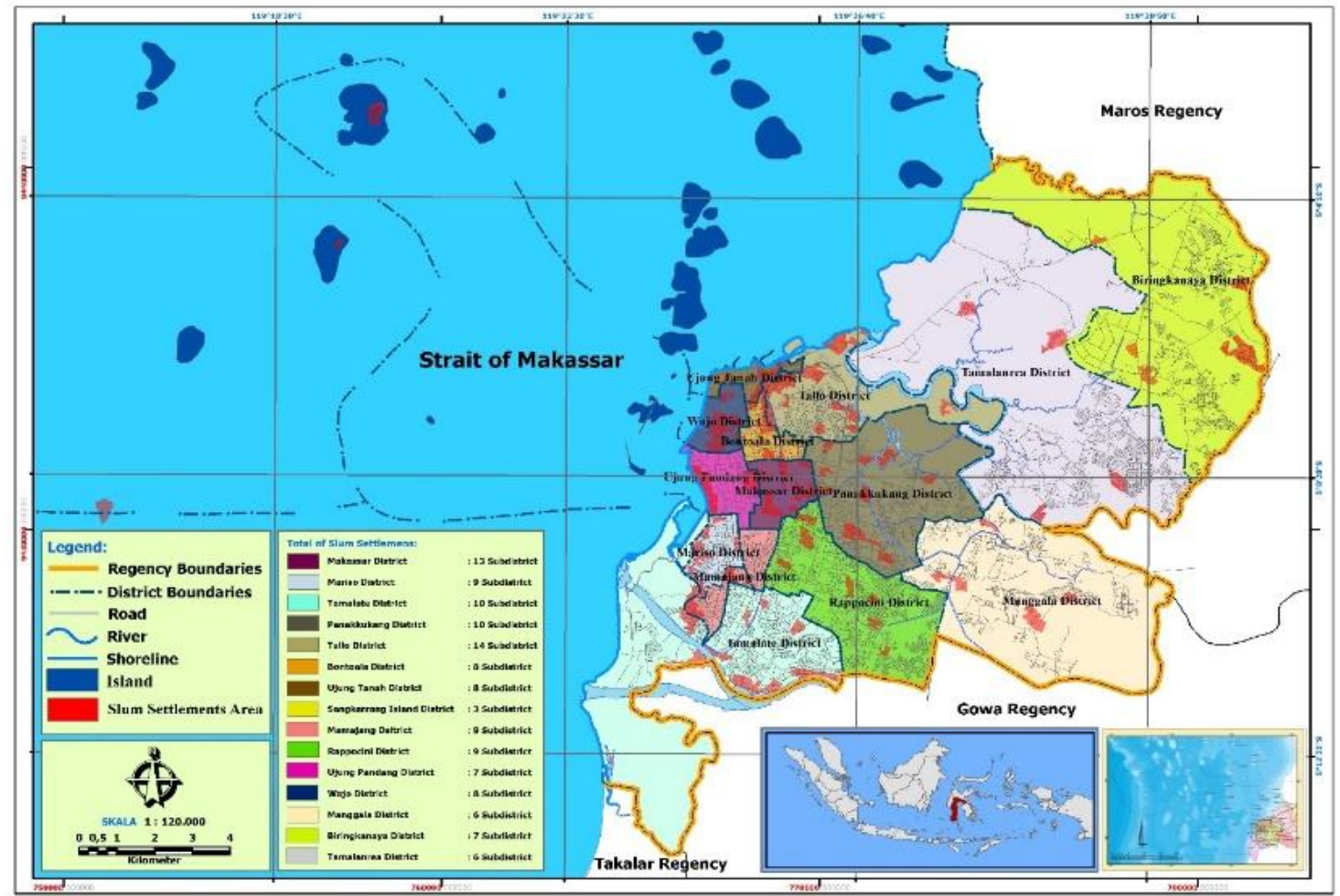

Fig. 2. Makassar City Slum Settlement as a study object. Source: Makassar City Bappeda, 2019.

\section{Method of Collecting Data}

The data source in this research are:

(1) the handling of slum settlement in the Makassar City; the data source was obtained through observation, in-deep interview, survey, and documentation; (2) direct and indirect influence about the slum settlement handing towards the improvement of the quality of slum settlement environment, the data source was obtained through observation and survey; (3) spatial integration and sustainable slum settlement, the data source was obtained through observation, interview, survey, and documentation.
Thus, the study approach chosen in this study is case study. Case studies were chosen for several reasons: (a) spatial integration in the dynamics of the Makassar City development is specific and complexly arranged; (b) the developing slums have a very prominent pattern, consistency, and sequence; (c) the context of the case handling of the slums of the Makassar City is quite complex, covering infrastructure, economy, social, and environment; and (d) the nature of the case of the sustainability of the handling of the slums of the Makassar City aimed at understanding the social, economic, 
and environmental conditions that have direct links with the spatial integration of the Makassar City. Thus the data collected through observation, in-depth interviews, structured interviews, questionnaires, and documentation.

Observations in this study are related to two things, namely information and context. The information collected is adjusted to the questions raised in indepth interviews and questionnaires. Furthermore, data collected in this process, namely (i) handling slum infrastructure, (ii) controlling environmental pollution, (iii) socioeconomic empowerment of the community, (iv) slum quality improvement program, and (v) sustainability of slum settlement management programs. Furthermore, indepth interviews were conducted for two purposes, namely (i) description, and (ii) exploration. In-depth interviews in this study will use tools such as; tape recorder, pictures, and interview guidelines supplemented with; Freelance notes, checklists, and value scales. In-depth interviews were used to trace data: (1) community participation in program implementation; (2) economic and social empowerment mechanism implemented; and (3) Makassar City slum quality improvement environment program.

The questionnaire in this study was used for two functions, namely (i) descriptive, and (ii) measurement. The purpose of using the questionnaire is to provide an overview of some characteristics of individuals and community groups. The use of the questionnaire was used in tracking data including: (i) level of education, (ii) social structure, (iii) type of work, (iv) level of income, (v) social relations, (vi) community institutions, and (vii) ownership housing facilities and land ownership status. The structured interview conducted refers to the questions in the questionnaire that have been set. The questionnaire was not submitted to the respondent but was guided by the researcher. Furthermore, the selection of respondents is carried out by field workers. The chosen enumerators are based on consideration, namely those who have the ability to collect data, be close to the community, and understand the socio-cultural conditions of the community.

In this research, various documents are used, among others: (i) land ownership status, (ii) data on the number of inhabitants living in slums, (iii) 
community profiles, and (iv) data on slum settlement management activities. The documentation collected in this study, namely Makassar City in Figures 2019 and Districts in Figures 2019. Furthermore, the data collected was then triangulated by combining observations, in-depth interviews and documentation simultaneously. The aim is to test the credibility of the data and for the sake of deepening the spatial integration of work as a determinant of the sustainability of the handling of slums.

\section{Determination of Research Informants and Respondents}

Informants in this study, used for qualitative data collection. Determination of informants using the snowball method. As the informant the researcher identified one of the community leaders who inhabited the location of the slums. Furthermore, informants were also determined from several respondents who had been interviewed before. The aim is to explore some of the questions that will be answered in a questionnaire that requires a more detailed explanation. The number of informants determined was 15 people. 5 people came from outside the respondent and 10 more people came from respondents. Next, quantitative data were collected from respondents or research samples. The sample is determined using a purposive sampling technique which is determined by the researcher based on specific characteristics. The characteristics referred to by the researcher are the samples are the people who are located in the slums of the Makassar City, are married, live or have not moved for at least five years. Furthermore, these characteristics are used by researchers in determining respondents. The sampling method was in accordance to Cochran (1977), as follows:

$$
n=\frac{N}{N d^{2}+1}
$$

where $n$ refers to the sample size, $N$ refers to the population size, and d refers to the error rate $(0.5)$ or $5 \%$ of the $95 \%$ confidence level. The number of samples in this study were set at 400 respondents. The research sample included 127 slums locations distributed in 15 sub-districts.

\section{Data Analysis Technique}

There are two processes of activities carried out by researchers in data analysis. First, conducting qualitative research where data collected through observation and in-depth interviews are then analyzed. Second, conducting quantitative research, researchers gather information on research objects using a questionnaire instrument. The analysis method in this research was divided into several 
categories, they are: (i) statistic descriptive quantitative, which is used for the survey result data, (ii) documentation study, uses content analysis towards the data obtained through observation and the data

from the result of focus group discussion, (iii) the assumption established in this research are; the correlation between $\mathrm{X}_{1}$ and $\mathrm{X}_{2}$, correlation between $\mathrm{X}_{1}$ and $\mathrm{X}_{3}$, and the correlation between $\mathrm{X}_{2}$ and $\mathrm{X}_{3}$. Such assumption was then tested using Path analysis method. The variable determined in this research are: (a) settlement infrastructure $\left(\mathrm{X}_{1}\right)$, controlling of environmental pollution $\left(\mathrm{X}_{2}\right)$, (c) social-economy empowerment $\left(\mathrm{X}_{3}\right)$, (d) quality improvement of slum settlement environment ( $\mathrm{Y})$, and (e), the sustainable handling of slum settlement (Z). The path diagram used structural equations, as follows:

$\mathrm{Y}=\mathrm{PYX}_{1}+\mathrm{PYX}_{2}+\mathrm{PYX}_{3}+\mathrm{e}_{1}$

Path analysis was used with the following considerations: (1) The research metric data usea interval scales; (2) there are endogenous dependent and exogenous independent variables for multiple regression models and intermediate variables for mediation models, as well as combined mediation and multiple regression models and complex models;
(3) there is a sample size of 400 respondents; (4) the pattern of relationships between variables is only unidirectional; and (5) there is a causal relationship based on theory, that is, there is a relationship or correlation between handling infrastructure, controlling environmental pollution, and socioeconomic empowerment towards improving the quality of slums and the continuity of handling slums. Analysis of the application path is shown in Figure 3.

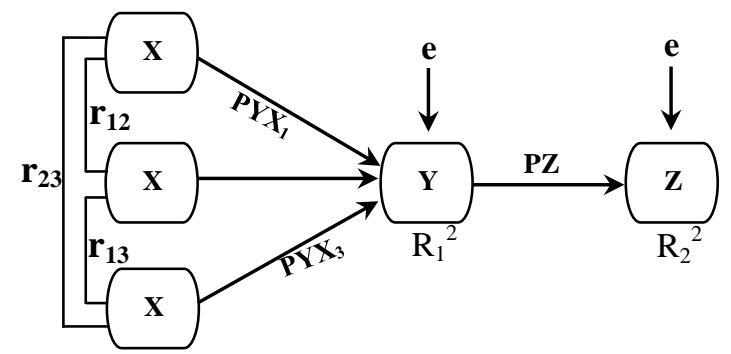

Fig. 3. Model of path analysis.

Furthermore, data analysis is done by combining analysis of qualitative and quantitative data. That is, the steps used for qualitative research at the same time are also used for quantitative research. At the time of interpretation or analysis, each data is carried out reduction, namely for qualitative data categorization and quantitative data, descriptive statistical calculations and path analysis are performed. The two data are then interpreted triangulated or between methods. That is, the data obtained through the questionnaire will be explored 
more deeply through two methods, stages of data collection and data analysis namely qualitative and quantitative. The in this study are illustrated in Figure 4.

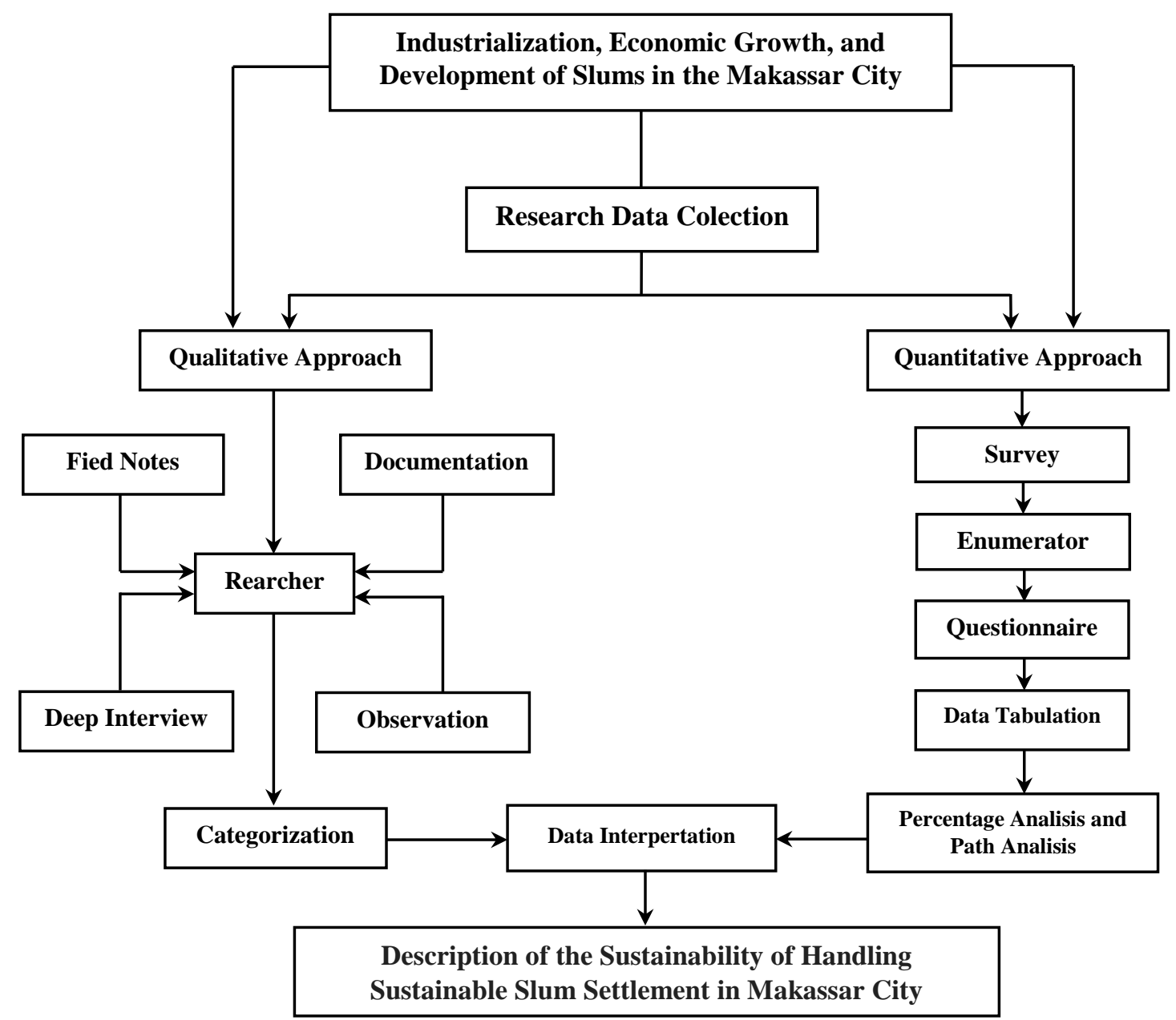

Fig. 4. Combination of qualitative and quantitative approaches. Source: Adapted from Saefullah, 1993, with modification.

\section{B. RESULT AND DISCUSSION}

The accelerated development of the Makassar City as a national center and core city in the Mamminasata Metropolitan urban system, is characterized by the conversion of land use functions and the conversion of productive agricultural land towards the establishment of service centers and the integration of urban systems.
Urbanization and migration of the population in the dynamics of the development of the Makassar City, have an impact on the spatial physical transition towards the formation of a very complex social area structure. The space in the process of urbanization is undergoing a great transition from physical space to social space (Ye, C, et al., 2017). Urban urbanization that tends 
to be excessive causes slums to develop, community segmentation, segregation, and spatial separation of social areas. Rapid urbanization, will result in multiscalar separation, which involves the separation of time scales, separation of space scales, and social separation (Ye, C, et al., 2014). Furthermore, spatial integration and the formation of urban systems have an impact on spatial interaction and increased population mobility. The process causes changes in spatial structure and spatial patterns towards ecosystem complexity, deterioration in environmental quality, changes in land tenure status, and developing slums.
The development of slums in the Makassar City is influenced by three main factors, namely (1) community poverty; (2) the inability of the community to get decent work; and (3) socio-economic inequality and land tenure. Urbanization is seen as the urbanity level or the percentage of the population which is high enough in the direction of urban form and has the influence towards social environment, economy, and nature (Kusumawijaya, 2006; Wang, H, et al., 2017). The development of population number of the Makassar City could be seen on the following Figure 5.

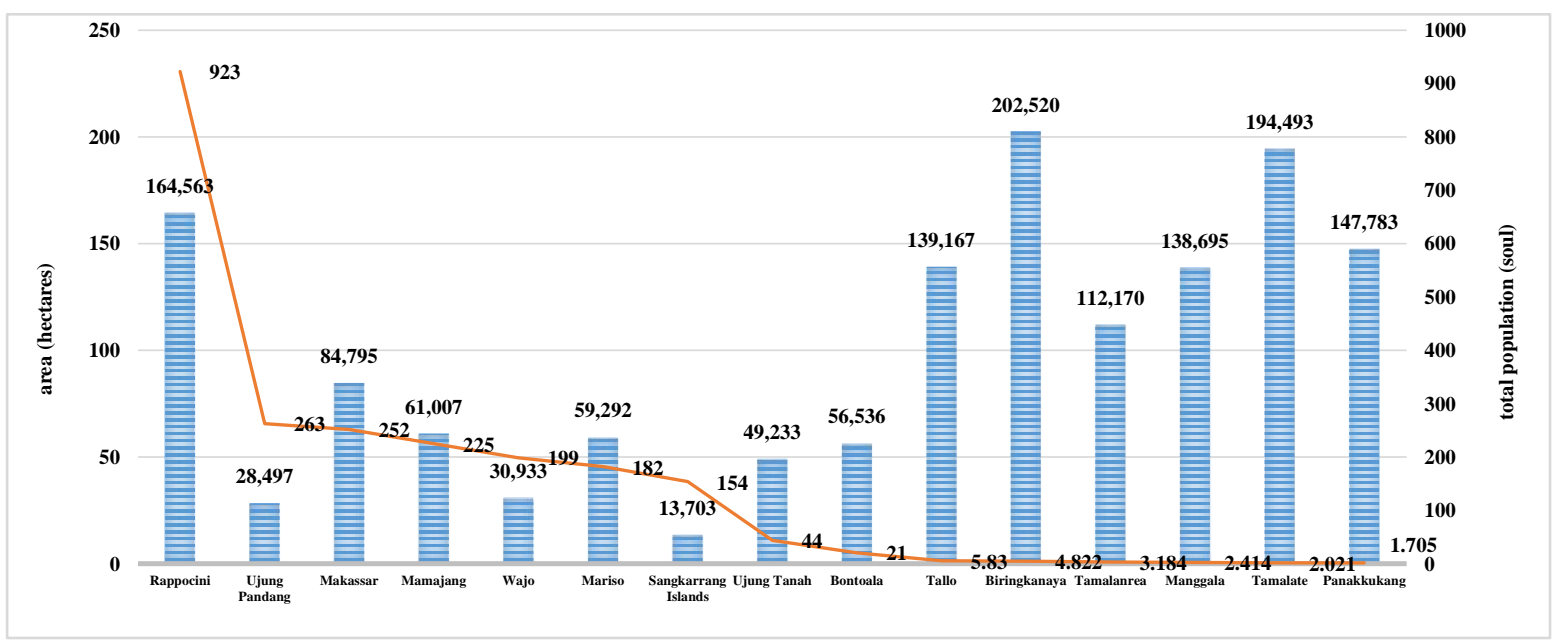

Fig. 5. Population and area of the Makassar City. Source: Makassar City Bappeda, 2019

Figure 5, shows the highest located in Sub-district Sangkarrang Island population was located in Sub-district with 13,703 people or $0.92 \%$ of the total Biringkanaya with 202,520 people or population. The urbanization process have $13.65 \%$. While the lowest population was important implications for designing 
necessary policies and regulations (Patra, S, et al. 2018). Informal settlements, or slums as they are often called, also comprise a significant and increasing proportion of residential dwellings in cities across the developing world (Chakraborty, A, et al. 2015). Further, the location and intensity of development based on the carrying capacity of the area have not been worked out or stated in the building regulations thereby creating the mismatch in the supply and demand of the infrastructure provisions and services (Jawaid, M.F et al. 2018). Intensity of segregation and developing slum settlement on illegal land has a positive correlation towards the difficulty in the fulfillment of green open space for the government inability in maintaining city development (Sintusigha and Mirgholami, 2013). Creation of new elite spaces within the inner city, have shaped a complex pattern of socio-spatial differentiation and residential segregation $(\mathrm{Wu}, \mathrm{Q}$, et al. 2014).

\section{Characteristics and Typology of Slum Settlements in Makassar City}

Typology of slum settlement in the Makassar City was divided in three categories, they are: (i) lowland slum of 284,99 hectares, (ii) lowland slum and water edge of 310,96 hectares, and slum lowland, water edge, and above water of 80,36 hectares. Furthermore, based on the characteristic of slums it is divided into two main category they are: (a) medium slum of 216,32 hectares and light slum of 459,99 hectares. The fact that the field is found illustrates that the typology and spatial physical characteristics of slum locations have differences based on patterns of use of the built space. The difference in the use of slum space shows that the environmental characteristics and variations in community work in handling it will require different mechanisms and procedures including in the relocation of community settlements. The composition of the environment and access to employment implies that the relocation program must be carefully designed if it is to improve welfare (Takeuchi, A. et al., 2008). The characteristic and typology of slum settlement of Makassar city could be seen in the following Figure 6. 

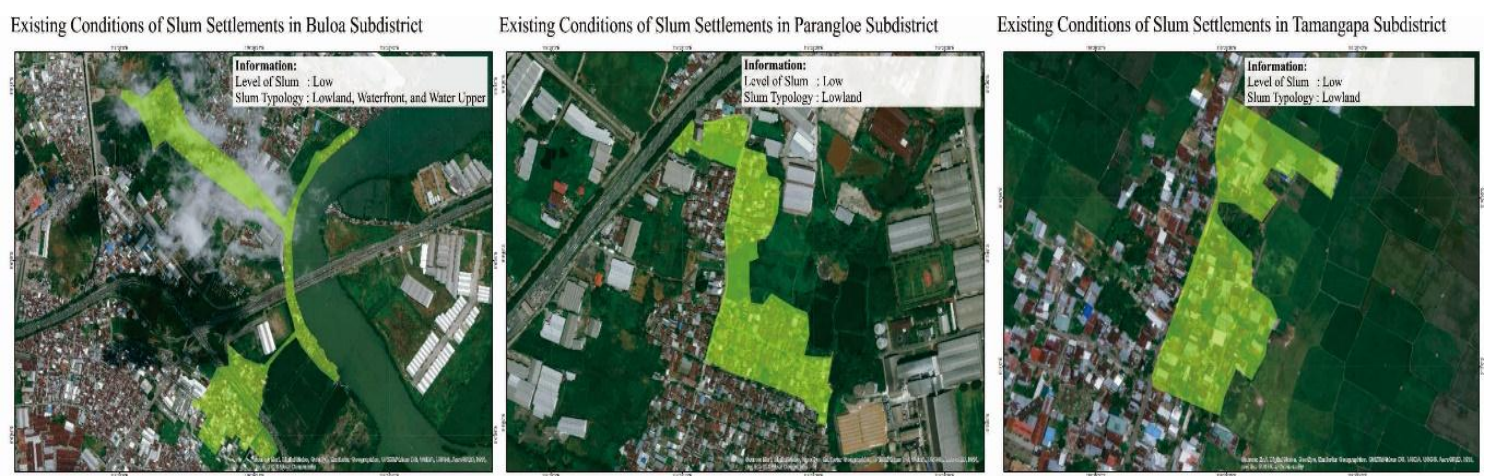

Existing Conditions of Slum Settlements in Mangasa Subdistrict

Existing Conditions of Slum Settlements in Tallo Subdistrict

Existing Conditions of Slum Settlements in Pannampu Subdistrict
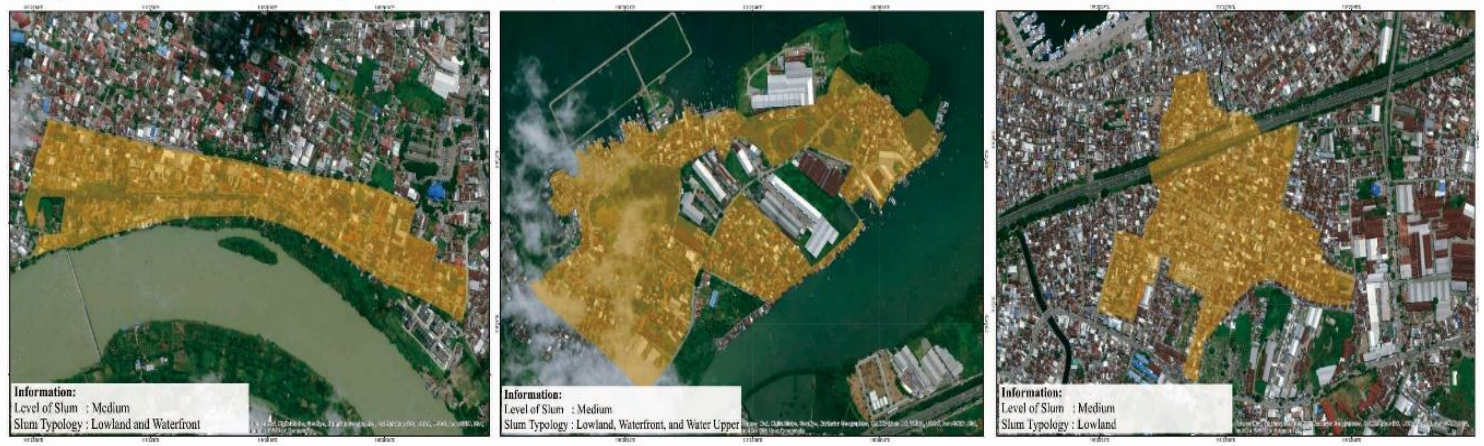

Fig. 6. Examples, characteristics and typology of slum settlements in the Makassar City. Source: Map ${ }^{(\mathrm{c})} 2019$ Google.

Figure 6 shows the typology and characteristics of slums in the Makassar City.

Three interpretations that can be proposed related to these conditions, namely (1) slums located in low-lying areas. Slums in this location predominantly have legal land status and orientation of population activities in the urban informal sector; (2) slums located on the water's edge. The dominant slums are the status of illegal land and the orientation of the activities of the dominant population are fishermen and urban informal activities; (3) slums located on water. This slum settlement has the status of illegal land and the orientation of the activities of the dominant population as fishermen. The existence of slums is characterized by a decrease in environmental quality. Furthermore, based on its location it is very vulnerable to the threat of floods, fires, and the spread of infectious diseases due to inadequate infrastructure and support, including the inadequacy of residential buildings and urban social problems. The living conditions of people living in slums are characterized by overcrowding, insecure residential ownership, and / or poor access to infrastructure, such as sanitation facilities (Friesen, J, et al., 2020).

The increase in economies of scale and the spatial integration of the Makassar 
City in the surrounding cities as a unity in the Metropolitan Mamminasata urban system, have an impact on increasing the need for housing and settlements. Field facts found indicate that the orientation of economic development towards the development of new growth centers in addition to an impact on increasing housing needs facilitated through developers on the one hand, on the other hand also contributes positively to the increase in slums located in areas that must be protecte. Slum neighborhoods negatively impact sustainable house rental values, as compared with the rental values of houses located far away. Rents became higher as the distance from the slums increased (Surya, B, 2015; Hussain, T, et al., 2019). Furthermore, spatial integration that runs along withe the development of slum settlement, affects the adaptability of the people in facing spatial situation that continuously changes from the spatial structure side, spatial pattern, and the dynamic pattern of socio-economy activity developed in the Makassar City. The spatial pattern of urban community is the key to the resilience of community structure in the face of change able environment, while indicators such as the distribution, formation, location and function of spaces have direct influences on the structural resilience (cai Wang, Y, et al., 2018). The distribution of slum settlement in the Makassar city could be seen in the following Figure 7.

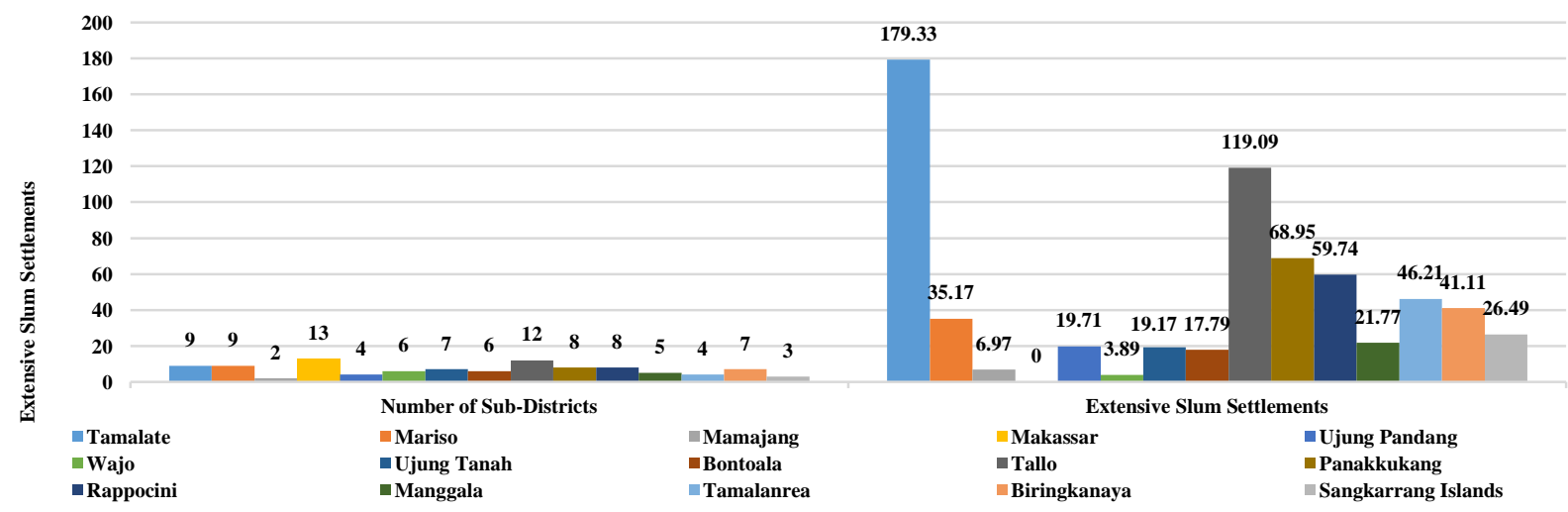

Fig. 7. Distribution of slum settlements in the Makassar City by District. Source: Makassar City Bappeda, 2019

Figure 7 shows the distribution of indicators: (1). Conditions of the Makassar City slums located in 15 infrastructure services, including; (i) road sub-districts. The classification, level of slums, and the typology of slums in Makassar are differentiated based on networks, (ii) drainage networks, (iii) clean water services, (iv) environmental sanitation, (v) waste systems, (vi) 
potential fire threats, (vii) residential buildings, and (viii) provision of green open space. (2) Pollution of the residential environment, including (i) soil pollution, (ii) water pollution, and (iii) air pollution. (3) Economic conditions, including welfare level, (ii) community income, and (iii) business patterns of economic activity. (4) Social conditions, including (i) social structure, (ii) social system, (iii) social conflict, (iv) urban crime, (v) community behavior. (5) Location suitability of spatial planning, including (i) location legality, (ii) land status, (iii) development area. Furthermore, interpretations that can be submitted are related to the existence of slum areas, namely (i) the existence of slum areas that develops positively associated with the existence of poor and marginal communities; (2) settlement management is oriented to four main principles, namely community economic empowerment, increasing community participation, controlling environmental pollution, and strengthening community institutional capacity.

The handling of slum settlement in the Makassar City which is predominant on the improvement of infrastructure quality and the prevention effort which have not been optimal causes some social, settlement warranty, and economy business issues is less developed. Furthermore, the limitation of government funds for proper housing becomes the determinant factor of not optimal handling of slum settlement. The failure in controlling informal settlement is because the implementation strategy was applied in the form of public mediation (Dall'Orso and Barsallo, 2017). Field fact found shows a tendency that the slum settlement developed in the Makassar City seen from the location does not match with the direction of urban spatial planning determined and dominantly located in the area that must be protected.

Various program has been done by the government in providing settlement especially for poor people, the pattern used in the target fulfillment however is still oriented on the supply and not based on the level of people's need. Urban growth by levering manufacturing and real estate capital, it has also introduced constraints for future urban development by generating inter-regional tensions and making further reforms politically difficult (Wang, L, 2014). The characteristic of slum settlement in the Makassar City could be seen on the following Figures 8 . 


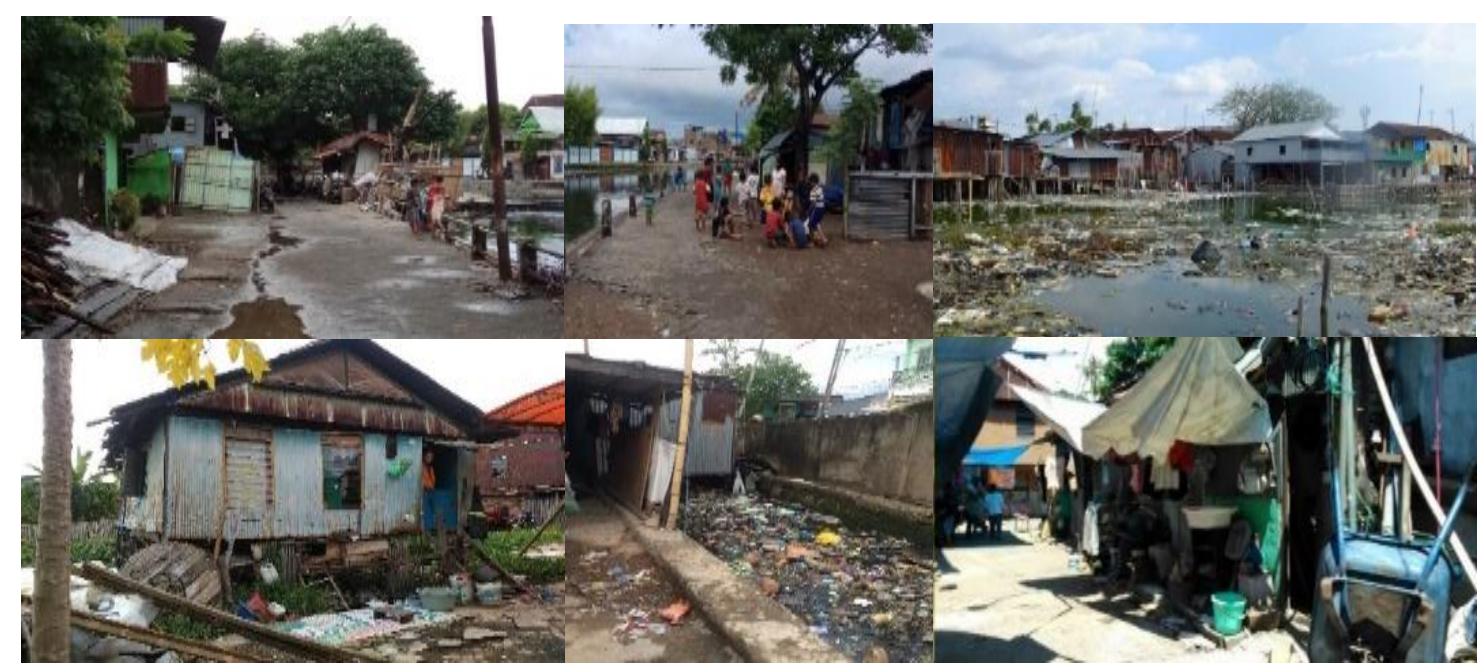

Fig. 8. Example, characteristics of slum settlements in the Makassar City. Source: Primary Data

Figure 8 shows the existence of slums related to the condition of settlement infrastructure, economic, social, and the inadequacy of residential facilities. The existence of slum settlement that could be explained: (1) characteristic and type of housing is dominantly staged housing with subsistence material; (2) sufficiently high charge of environmental pollution; (3) the availability of limited green open space; (4) very bad environment sanitation; (5) people's behaviour, littering on the drainage; and (6) the condition of road surface that does not fulfill technical standard. Housing market reformed over the last decade has intensified the differentiation of housing price and new housing distribution, especially those of high-priced commercial housing, resulting in a slightly strengthened residential segregation between local and migrant elderly people (Liu, Y, et al., 2015; Surya, 2015b). The the voluntary sector has been regarded as the nation's third sector which gives a direct impact on the economy, thus, the results in community well-being (Mohd Nor, et al., 2018).

The filed fact found shows that the procurement of livable housing is dominantly for those with middle income who live in the "legit" slum location must go out of such location by replacing the old resident with the new one. Such process affects the missing community cultural value for being replaced by modern community cultural value. During the urban transformation process, the onesided pursuit of speed and "modernization" has resulted in ignoring 
the inheritance and innovation of traditional culture and demolishing many "old buildings" and "old neighborhoods" with historical stories and cultural value (Guan, X, et al., 2018). Furthermore, the inability of the people to have proper living place facility for being displaced creates newly developed and dominant slum settlement by poor people. The number of poor people in the Makassar City is based on the sub-districts in Figure 9 below.

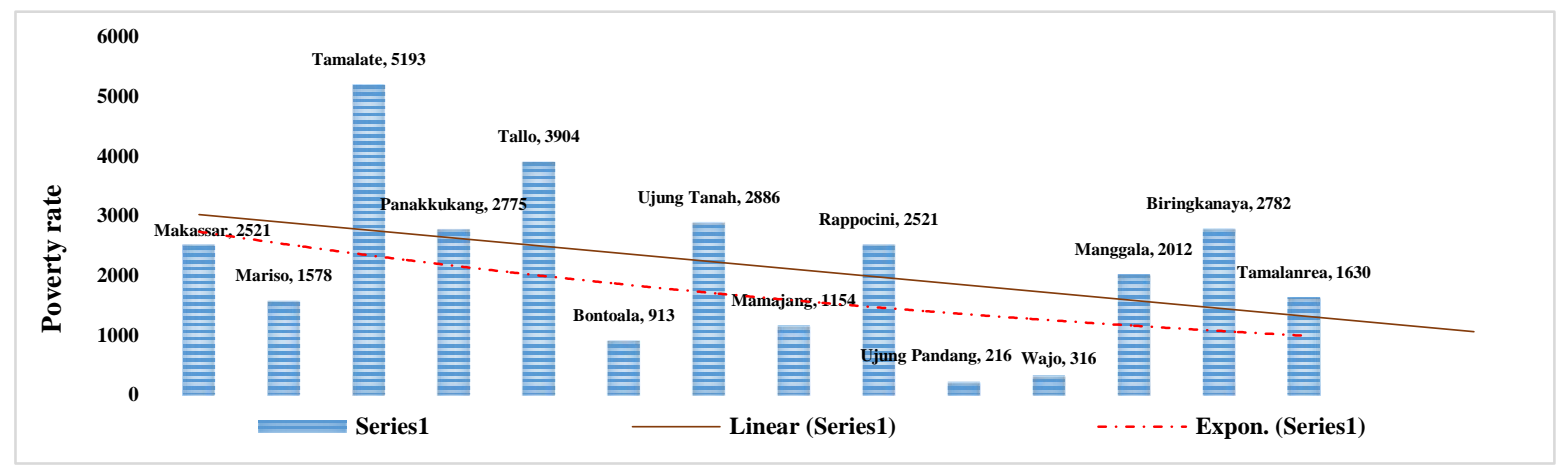

Fig. 9. Population poverty rate of the Makassar City by district. Source: Makassar City Bappeda, 2019.

Figure 9 shows the distribution of the poor population by district in the Makassar City. The number of poor people who tend to increase every year is positively associated with economic growth and urbanization. The direct impact that can be observed is social exclusion and imbalance of urban settlement infrastructure services. Field facts found indicate that growing infrastructure and socio-economic service gaps will threaten the sustainability of the urban environment. Furthermore, the trigger factor for the high poverty rate in the Makassar City is not only due to the factor of community helplessness but also due to limited employment and formal urban activity patterns. This condition becomes a difficulty for the community to access employment opportunities due to limited expertise, skills, and inadequate educational background, causing slums to develop.

People's poverty which is quiet prominent is located in sub-district Tamalate with the number of 5.193 people or $0.35 \%$. Moreover the lowest poverty is located in Sub-district Ujung Pandang with 216 people or $0.01 \%$ of the total population of the Makassar City. Poor people group is then developing housing along the river bank, coast, or on the abandoned land and positively associated with the social conflict slum 
settlement develops on the status of illegal land (Surya, B, et al., 2018). Thus, an increase in the number of poor people in the Makassar City is positively associated with the existence of slums by occupying land that is illegal and has an impact on environmental quality. Finally, the oftendiscriminatory displacement that accompanies inner city redevelopment also tends to trigger social conflict (Zhang, C, et al., 2012).

\section{Spatial Integration and Slum Settlement of the Makassar City}

The spatial integration of the Makassar City is positively associated with the formation of an urban activity system towards economic growth and urban agglomeration. The tendency of agglomeration has an impact on the unification of the Metropolitan Mamminasata urban system. The adequate transportation infrastructure support causes the relationship between the city center and the periphery to be of high intensity. An appropriate transportation system will be able to support the economy and social activities, as well as contribute to environmental protection and resource-effective utilization (Marsden, G, 2007). Urban agglomeration and the dominant spatial integration are oriented towards the development of the largescale settlements, centers of trade and services, industry, and higher education. Urban agglomerations have become the urbanized "growth poles", especially against the background of increasing population flow to cities (Surya, B, 2015; Lan, F, et al., 2019). The existence of functions of socioeconomic activities on a regional service scale contributes positively to the conversion of productive agricultural land, changes in spatial use, environmental degradation, population mobility, slums, and community marginalization. The vital function of cities is to provide affordable infrastructure and institutional environments that enable migrants and other marginal urban communities to contribute to urban prosperity and problem solving with their entrepreneurial skills, networks, and minds (Aerni, P, 2016).

The development of the formal settlement developed by the developer which is completely and luxuriously designed and facilitated by the developer has changed the spatial physical characteristic of the Makassar City consistently to the big scaled housing development supported by adequate infrastructure development and connected to the urban economic activities. Urban 
form's consistent effect on facility probabilities emphasized the impacts of streets or road design layouts and urban densities on the daily services and amenities provision (Lang, W, et al., 2019).

Slum settlement developed by the poor people independently shows the limited infrastructure service and develop to the fragmentation of the community with social and economy gap. Suburbanization of poverty caused not only by direct moves but also by broader indirect and exclusionary processes attributable to the increasing inaffordability and inaccessibility of central city locations (Hochstenbach and Musterd, 2018). Spatial integration in handling slum settlement is oriented on several items, such as; (i) the improvement of slum settlement location accessibility towards urban functional, (ii) rejuvenation of slum settlement environment which is integrated to the urban system, and (iii) slum settlement setup through the development of integrated local economy to the economy system of the Makassar city. In the integration process, a special effort must be concentrated in the identification of favelas and the counting of their population to avoid (Carr-Hill's, 2013), concern that a portion of the slum population is not counted by government agency (Pedro, A.A \& Queiroz, A.F, 2019).

Classification or slum settlement assessment of the Makassar City is based on the handling urgency: (1) location suitability towards the city layout plan, has the highest urgency value and related to the living warranty for the people with the weight value of 20 ; (2) the infrastructure quality improvement and environment pollution has 15 weight takes the second priority; and (3) other parameter has weight value of 10 is the third priority in handling slum settlement. Furthermore, the determination of the parameters for handling the slums of the Makassar City based on the realization that has been carried out in Table 1 below. 
Table 1. The parameters for handling the slum settlement of Makassar City.

\begin{tabular}{|c|c|c|c|c|c|}
\hline Number & $\begin{array}{c}\text { Slum Settlement } \\
\text { Handling }\end{array}$ & Parameter & Value & Weight & Scoring \\
\hline \multirow[t]{8}{*}{1} & Infrastructure & - Street & 8 & & $\overline{1,2}$ \\
\hline & & - Drainage & 8 & & 1,2 \\
\hline & & $\begin{array}{l}\text { - Drinking water } \\
\text { service }\end{array}$ & 4 & & 0,6 \\
\hline & & - Sanitation system & 3 & 15 & 0,45 \\
\hline & & - Waste facility & 3 & & 0,45 \\
\hline & & - Fire protection & 2 & & 0,3 \\
\hline & & $\begin{array}{l}\text { - Waste Water } \\
\text { processing }\end{array}$ & 2 & & 0,3 \\
\hline & & Sub Total & 30 & & 3,0 \\
\hline \multirow[t]{4}{*}{2} & Condition of Living & - Permanent & 2 & & 0,2 \\
\hline & Building & - Semi Permanent & 4 & 10 & 0,4 \\
\hline & & - Temporary & 8 & & 0,8 \\
\hline & & Sub Total & 14 & & 1,4 \\
\hline \multirow[t]{7}{*}{3} & Pattern of relatedness & - Trading & 8 & & 0,8 \\
\hline & of Slum Settlement & - Service providing & 7 & & 0,7 \\
\hline & Space & - Education & 6 & 10 & 0,6 \\
\hline & & - Health & 4 & 10 & 0,4 \\
\hline & & - Office & 3 & & 0,3 \\
\hline & & - Industry & 8 & & 0,8 \\
\hline & & Sub Total & 36 & & 3,6 \\
\hline \multirow[t]{3}{*}{4} & Community Activity & - Economy Activities & 8 & & 0,8 \\
\hline & Pattern & - Social Activities & 8 & 10 & 0,8 \\
\hline & & Sub Total & 16 & & 1,6 \\
\hline \multirow[t]{4}{*}{5} & Environmental & - Soil Pollution & 8 & & 1,2 \\
\hline & Pollution & - Water Pollution & 8 & 15 & 1,2 \\
\hline & & - Air Pollution & 8 & & 1,2 \\
\hline & & Sub Total & 24 & & 3,6 \\
\hline \multirow[t]{4}{*}{6} & Social Structure & - Social Stratification & 8 & & 0,8 \\
\hline & & - Social Status & 8 & 10 & 0,8 \\
\hline & & - Social Class & 8 & & 0,8 \\
\hline & & Sub Total & 24 & & 2,4 \\
\hline \multirow[t]{4}{*}{7} & Cultural Pattern & - Value System & 7 & & 0,7 \\
\hline & & - Social Norms & 6 & 10 & 0,6 \\
\hline & & - Social Capital & 8 & & 0,8 \\
\hline & & Sub Total & 21 & & 2,1 \\
\hline \multirow[t]{4}{*}{8} & Location Suitability & - Very Suitable & 3 & & 0,6 \\
\hline & towards Layout Plan & - Fairly Suitable & 2 & 20 & 0,4 \\
\hline & & - Not Suitable & 8 & & 1,6 \\
\hline & & Sub Total & 13 & & 2,6 \\
\hline
\end{tabular}


Related interpretation proposed (Table 1), such as: (1) slum settlement handling focus more on the improvement of infrastructure quality oriented to enable the system of population movement; (2) the population activity pattern includes the providing of economy business and education facility; (3) the controlling of environmental pollution oriented to the handling of land, water, and air pollution; (4) social structure is oriented more on the business of economy business and the preparation of occupancy; (5) the handling of building quality for living is focused on the improvement of technical building feasibility; (6) the handling of cultural pattern is oriented more on the creation of harmony in the live, of the people based on the values they embrace together; (7) activity pattern of the people is focused more to encourage business productivity improvement and the improvement of community institutional capacity; and (8) location suitability of slum settlement towards the layout plan is oriented more on the land legality status on the areas that must be protected. The path analysis results in Figure 10 below.

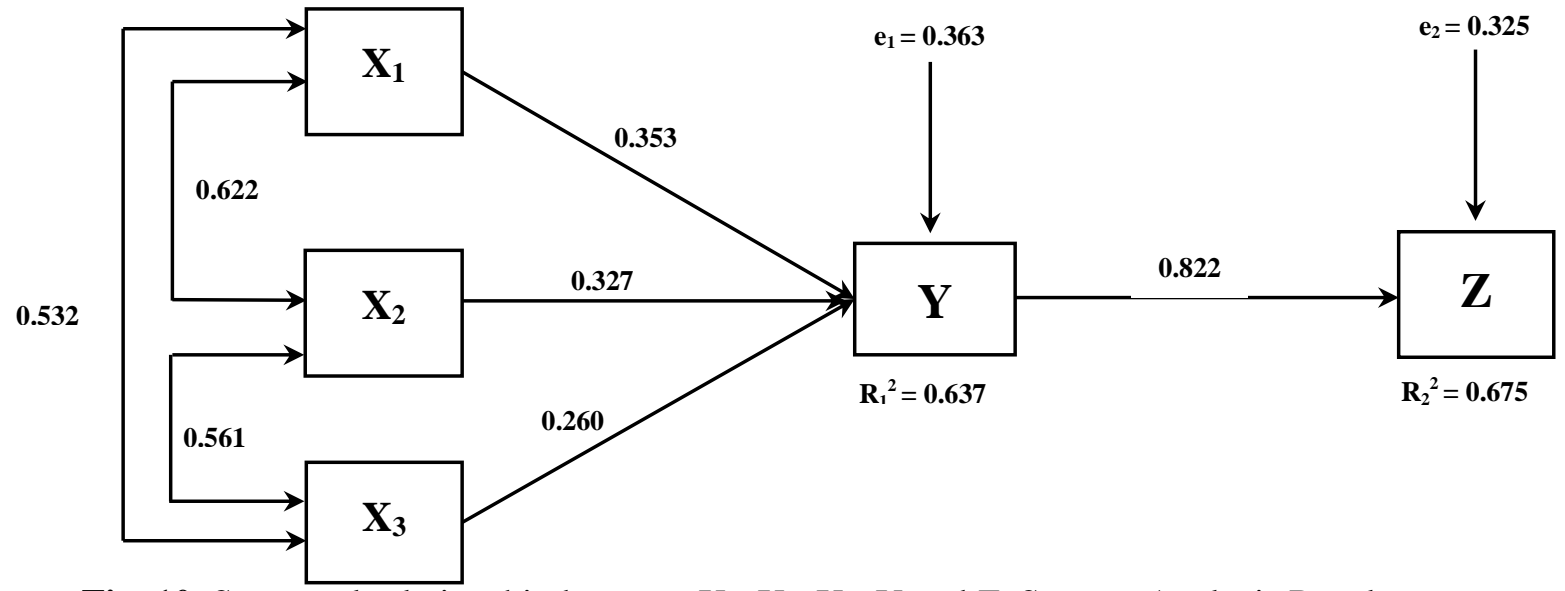

Fig. 10. Structural relationship between $X_{1}, X_{2}, X_{3}, Y$ and Z. Source: Analysis Results.

Figure 10 shows the results of the path analysis, which can be explained including: (1) relation or correlation between infrastructure and the environmental pollution control is 0.622 (i.e., 62.2\%); (2) the relation or correlation between infrastructure variable and social economy empowerment is 0.532 (i.e., 53,2\%); and
(3) the relation or correlation between environmental pollution control and social economy empowerment is $0.561(56.1 \%)$. Infrastructure direct influence towards the improvement of environment quality is 0.1246 (i.e., $12.46 \%$ ). Direct influence of environment pollution control towards the improvement of environment quality is 0.1069 (i.e., 10.69\%). Direct influence of 
social-economy empowerment towards the improvement of environment quality is 0.0676 (i.e., 6,76\%).

Indirect influence of infrastructure through environment pollution control towards the improvement of environment quality is $0.0718(7.18 \%)$. Indirect influence of infrastructure through social economy empowerment towards the improvement of environment quality is 0.0488 (i.e., $4.88 \%$ ). Direct influence of environment pollution control through the improvement of environment quality is 0.0488 (i.e., $4.88 \%$ ). Indirect influence of environment pollution control through social economy empowerment is 0.0477 (i.e., $4.77 \%$ ). Indirect influence of social economy empowerment through environment pollution control is 0.0477 (i.e., $4.77 \%$ ).

Residue (other variable influence towards the handling of sustainable slum settlement which had not been researched is 0.3642 (i.e., $36.4 \%$ ). Furthermore, the improvement of environment quality (Y) affects the handling of sustainable slum settlement (Z). Direct influence of the improvement of environment quality towards the handling of sustainable slum settlement is 0.6757 (i.e., $67.57 \%$ ). Residue (other variable influence towards the handling of sustainable slum settlement which had not been researched) is $0.3243(32.43 \%)$. The analysis result shows that there has been enhancement towards $\mathrm{Y}$ is $63.58 \%$ and the influence of $\mathrm{Y}$ towards $\mathrm{Z}$ is $67.57 \%$. Therefore, it could be concluded that the existence of intervening variable $\mathrm{Y}$ caused the occurrence of enhancement from $63.58 \%$ into $67.57 \%$ (there has been an improvement is $3.99 \%$ ).

\section{Determinant of the Spatial Integration and Makassar City Economic Growth}

The dynamism of the development of the Makassar City which is oriented towards the center of economic growth has a positive contribution to its function and role as a core city in the Metropolitan Mamminasata urban system. This strategic role is closely related to the existence of socio-economic activities that functionally have driven the growth of secondary cities and small towns around it. Furthermore, the existence of a developing strategic economic function has an impact on increasing population mobility and increasingly intensive interregional relations. Cities are exchanging various flows such as material, energy, information, transportation, and migration (Han, J and Liu, J, 2018). 
This intensity is reflected through the role of transport services and the transportation network system in enhancing interregional, inter-city and interregional urban linkages. In different contexts spatial integration also has an impact on increasing the flow of urbanization and migration of residents around the core city to settle and settle in Makassar City. The direct impact of the process in addition to encouraging an increase in population, also had an impact on the high pressure on urban space. The trends of urbanization, and regard as the key to developing urban agglomeration, decentralized population flow, promoting healthy and stable development real estate market and advance sustainable urbanization (Lin, Y, et al., 2018). Furthermore, urbanization has brought with large populations in cities, which has then led to changes in urban land use intensity and spatial patterns, resulting in changes in underlying surfaces and urban climate (Jiang, Y, et al., 2018).

Spatial integration and urban agglomeration in the dynamics of the Makassar City development, in addition to triggering rural population migration, land use change, and environmental degradation, also have an impact on increasing the flow of goods and services towards increasing spatial interaction. Spatial interactions in line with the increase in urban activity have an impact on increasing the value and price of land in the core city of Makassar in the Metropolitan Mamminassata urban system. The increase in the value of the land has a direct effect on the accumulation of the population that forms a living network system based on the socio-economic strata of the community. Increasing population concentrations that continue to increase due to urbanization have an impact on the complexity of urban ecosystems.

The rapid growth of the Makassar City and is not matched by the provision of adequate housing and housing facilities and infrastructure has led to the development of slums. Furthermore, the high price of land affects the construction of houses with relatively small and limited parcels of land. As a result of the continuation is the creation of high population and building density, limited infrastructure services, and limited availability of land for the provision of green open space. Thus, it can be concluded that spatial integration, economic growth, urban agglomeration, urban urbanization, and increasing land values are determinants of developing 
slum settlements in the Makassar City. Furthermore, these factors are positively associated with decreasing environmental quality, economic imbalances, and social problems as an integrated system for handling urban slums in the Makassar City.

\section{Sustainability Slum Settlement Handling}

Urban area spatial integration of the Makassar City as caused by positive correlation of development towards the improvement of slum settlement on the areas that should be protected, so that it affects the environmental degradation and urban flood for the loss of drainage that should have been protected to support the continuity of city development. Gradual replacement of slums and squatter settlement with better residential quarters is also policy issue for government and local institutions (Uddin, N. 2018). Governments are likely to have a key role as either promoter or legitimator (or both), but other actors are also likely to have potential to contribute, especially social movements and civil society groups (Patterson, J.J, et al., 2018). There are two frequently used pattern to handle slum settlement in the Makassar city, they are: (i) by displacing poor people living in wild settlement on the area of river bank and coast, and (ii) by acting passive and tend to let the growth of spontaneous settlement for not having any instruments to handle it. External property-based interests in the renewal project areas enabled the full exploitation of development opportunities at the expense of poor owner-occupiers and tenants (Kyu HA, S and Hyun KWON, K, 2017).

Sustainable development concept as a solution to handle slums settlement in the Makassar City onward, are: (1) rejuvenation of slum settlement environment; (2) improvement of infrastructure quality; (3) establishment of flats as an effort to overcome slum settlement environmental issue; and (4) rejuvenation of progressive settlement environment by using CSR funds from private parties. Those four items have become the programs' determinant factors in handling slum settlement and become the movement of all and government agenda in order to manifest free slums of the Makassar City in near future. Urban informal settlements are growing rapidly, placing slum upgrading on the political agenda worldwide (Hachmann, 2018; Saleh, H, et al., 2020). Sustainability handling of the Makassar City slums in Figure 11 below. 


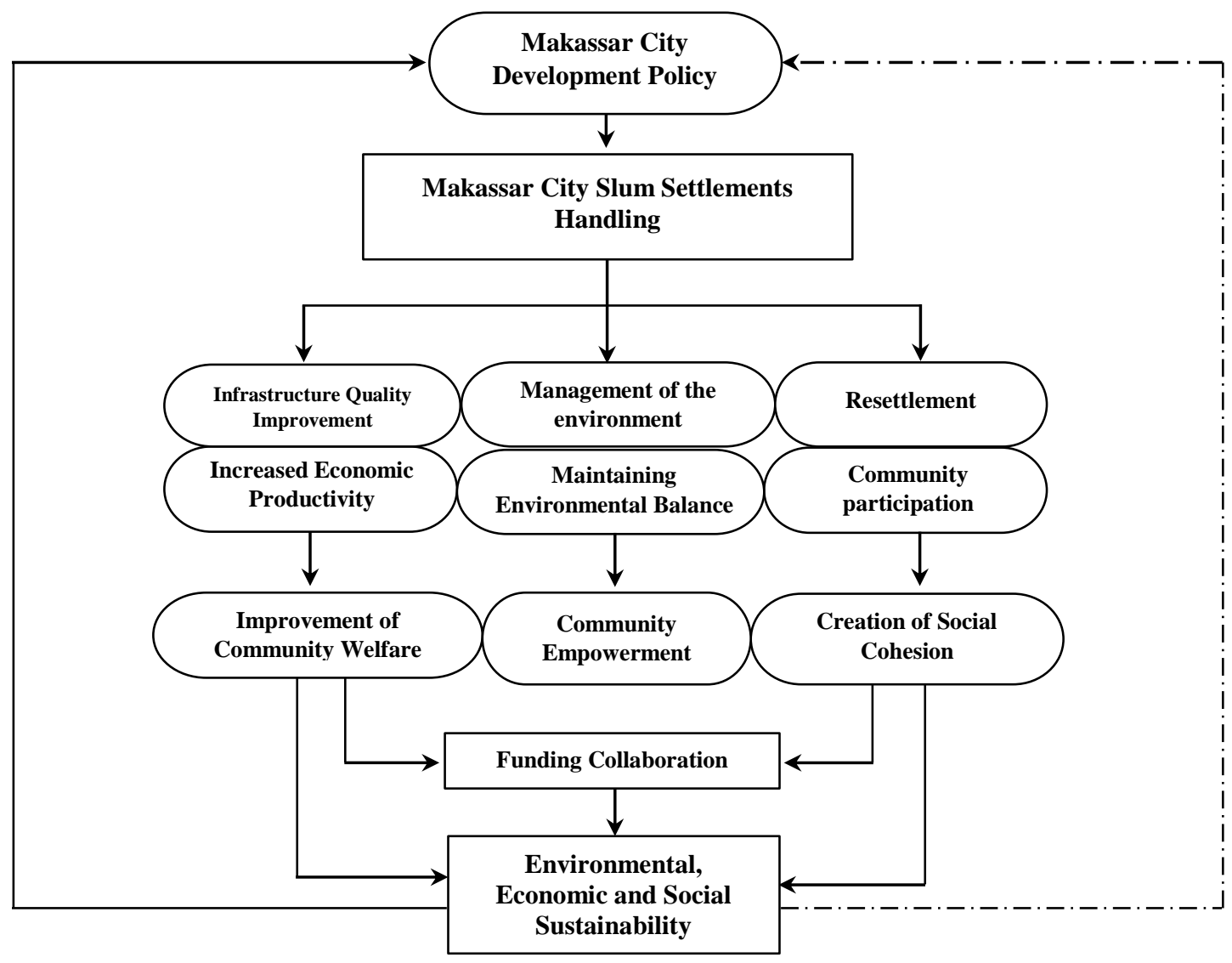

Fig. 11. Sustainability handling the Makassar City slums Source: Author's elaboration

The accelerated development of Makassar City towards spatial integration and economic growth has a positive contribution to the development of slums that are predominantly inhabited by the urban poor and the location is not in accordance with the established spatial plans. Spatial integration, economic growth, urban agglomeration, urban urbanization, and increasing land values are determinants of the development of slums in Makassar City and have an impact on environmental degradation, economic inequality, and social problems as whole urban system. Furthermore, slums located in areas that must be protected are characterized by a decrease in environmental quality and are very vulnerable to urban flooding, the spread of disease outbreaks, and the threat of fire. The handling of slums which is dominant in improving the quality of infrastructure causes the resolution of economic, social, and environmental pollution control problems that have not been handled properly and the mechanism has not been implemented in a comprehensive and integrated manner. 
The handling of slums settlement in the Makassar City in the future is oriented to the target fulfillment that have been determined by government by involving the active role of stakeholder, developing social capital to change the community behaviour, and the enhancement of government's institution capacity in formulating the policy that inclined to the poor people which is implemented through program integration and crosssectoral. The solution to handle the slum settlement in Makassar City forward, they are: (a) rejuvenation of slum settlement environment, (b) infrastructure quality improvement, (c) environment pollution control, (d) community's economy social empowerment, (e) the establishment of flats as an effort to overcome the problem of slums settlement, and (f) rejuvenation of the settlement environment which is more progressive using the CSR funds from the private parties.

\section{ACKNOWLEDGMENTS}

We are grateful for the participation of stakeholders in contributing ideas in carrying out this study. Thank you to the Ministry of Research and Technology of the Republic of Indonesia for their support and financial assistance in carrying out this research.

\section{REFERENCES}

Arsanjani, J.J., Helbich, M., Vaz, E.D.N. (2013). Spatiotemporal simulation of urban growth patterns using agent-based modeling: The case of Tehran. Cities, vol. 32, p. 33-42.

Adams, M., Klinsky, S and Chhetri, N. (2019). Barriers to Sustainability in Poor Marginalized Communities in the United States: The Criminal Justice, the Prison-Industrial Complex and Foster Care Systems. Sustainability,vol. 12(1), 220.

Aerni, P. (2016). Coping with MigrationInduced Urban Growth: Addressing the Blind Spot of UN Habitat. Sustainability, vol. 8(8), 800.

Buchecker, M and Frick, J. (2020). The Implications of Urbanization for Inhabitants' Relationship to Their Residential Environment. Sustainability, vol. 12(4), 1624.

Burns, P.A and Snow, R.C. (2012). The built environment $\&$ the impact of neighborhood characteristics on youth sexual risk behavior in Cape Town, South Africa. Health Place, vol.18(5), p.1088-1100.

Bappeda Makassar City. (2018). Data Updating Base and Mapping of Slum Areas (2018).

Bappeda Makassar City (2019). Makassar City in Numbers (2019).

Chakraborty, A., Wilson, B., Sarraf, S., Jana, A. (2015). Open data for informal settlements: Toward a user's guide for urban managers and planners. Journal of Urban Management, vol. 4(2), p.74-91.

Creswell, J.W. (2016). Research Design. Qualitative, Quantitative, and Mixed Method Approaches. 4th edition. Penerbit. Pustaka Pelajar.

Carr-Hill, R. (2013). Missing Millions and Measuring Development Progress. World Development, vol. 46,p. 30-44. 
caiWang, Y.,keShen, J.,ningXiang, W., QiongWang, J. (2018). Identifying characteristics of resilient urban communities through a case study method. Journal of Urban Management, vol. 7(3), p. 141-151.

Cochran, W.G. (1977). Sampling Technique 3rd ed. John Wiley and Sons, New York. 422 hlm. Available online: https://www.wiley.com/enus/Sampling+Techniques\%2C+3rd+ Edition-p-9780471162407. (Accessed on 12 Maret 2020).

Denzin, N.K and Lincoln, Y.S. (2009). HandBook of Qualitative Research. Penerbit. Pustaka Pelajar.

Dall'Orso, R.G., Gordón Barsallo, C.A. (2017). Boca la Caja and informal settlements in Panama. World Development Perspectives, vol.6, p.14-24.

Friesen, J., Friesen, V., Dietrich, I and Pelz, P.F. (2020). Slums, Space, and State of Health-A Link between Settlement Morphology and Health Data. Int. J. Environ. Res. Public Health, vol. 17(6), 2022.

Guan, X.,Wei, H., Lu, S., Dai, Q., Su, H. (2018). Assessment on the urbanization strategy in China: Achievements, challenges, and reflections. Habitat International, vol. 71, p. 97-109.

Hussain, T., Abbas, J., Wei, Z and Nurunnabi, M. (2019). The Effect of Sustainable Urban Planning and Slum Disamenity on The Value of Neighboring Residential Property: Application of The Hedonic Pricing Model in Rent Price Appraisal. Sustainability, vol.11(4), 1144.

Hachmann, S., Arsanjani, J.J., EricVaz. (2018). Spatial data for slum upgrading: Volunteered Geographic Information and the role of citizen science. Habitat International, vol. 72, p. 18-26.
Hochstenbach, C and Musterd, S. (2018). Gentrification and the suburbanization of poverty: changing urban geographies through boom and bust periods. Urban geography, vol. 39 (1), p. 26-53.

Han, J and Liu, J. (2018). Urban Spatial Interaction Analysis Using InterCity Transport Big Data: A Case Study of the Yangtze River Delta Urban Agglomeration of China. Sustainability, vol.10(12), p. 4459.

Izakovǐcová, Z, Mederly, $\mathrm{P}$ and Petrovi, F. (2017). Megatrends_Effects of Changes in Demographical Development and Urbanisation in Slovakia; Ekonomický ústav SAV: Bratislava, Slovakia. Sustainability, vol. 9(9), p. 1553.

Jone, P. (2017). Formalizing the Informal: Understanding the Position of Informal Settlements and Slums in Sustainable Urbanization Policies and Strategies in Bandung, Indonesia. Sustainability, vol. 9(8), p.1436.

Jawaid, M.F., Pipralia, S., Kumar, A. (2018). Review of environment responsiveness of building regulations in Jaipur. Journal of Urban Management, vol. 7(2), p.111-120.

Jiang, Y., Hou, L., Shi, T and Ning, Y. (2018). Spatial Zoning Strategy of Urbanization Based on Urban Climate Co-Movement: A Case Study in Shanghai Mainland Area. Sustainability, vol. 10(8), p.2706.

Kaya, A and Koc, M. (2019). OverAgglomeration and Its Effects on Sustainable Development: A Case Study on Istanbul. Sustainability, vol.11(1), p. 135. 
Kovacs, A.D., Lennert, J., Farkas, J.Z and Kanalas, I. (2017). Impacts and consequences of residential segregation of Roma in urban spaces: Case studies from Hungary. Urbani izziv. Vol.28(2), p. 136-147.

Kusumawijaya, M. (2006). City of Our Home. Jakarta: Borneo.

Kyu HA, S and Hyun KWON, K. (2017). In-Movers' Housing Choice and Gentrification in Seoul. Journal of Urban and Regional Analisys. IX (2).159-172. Available online: http://www.jurareview.ro/chapters/g et_chapter/106 (Accessed on 25 January 2020)

Lang, W., Chen, T., H.W.Chan, E., H.K.Yung, $\mathrm{E}$ and C.F.Lee, T. (2019). Understanding livable dense urban form for shaping the landscape of community facilities in Hong Kong using fine-scale measurements. Cities, vol. 84, p. 34-45.

Liu, Y., Dijst, M., Geertman, S. (2015). Residential segregation and wellbeing inequality over time: A study on the local and migrant elderly people in Shanghai. Cities, vol. 49, p.1-13.

https://doi.org/10.1016/j.cities.2015. 06.012

Lan, F., Da, H., Wen, $\mathrm{H}$ and Wang, Y. (2019). Spatial Structure Evolution of Urban Agglomerations and Its Driving Factors in Mainland China: From the Monocentric to the Polycentric Dimension. Sustainability, vol. 11(3), p. 610.

Lin, Y., Ma, Z., Zhao, K., Hu, W and Wei, J. (2018). The Impact of Population Migration on Urban Housing Prices: Evidence from China's Major Cities. Sustainability, vol. 10(9), p.3169.

McGee,T. (1971). The Urbanisation Procces in the Third World. Bell, London. Available online: https://www.persee.fr/doc/nnisn000 0-00001974num11867. (Accessed on 5 january 2020)

Mohd Nor, M.H., Alias, A., Musa, M.F. (2018). Social Capital in Youth Volunteerism. Planning Malaysia, vol.16 (4), p.176 -187.

Marsden, G. (2007). Defining and Measuring Progress towards a Sustainable Transport System. Available online: http://www.ncppp.org/wpcontent/uploads/2013/03/PS051012ValueForMoney-paper.pdf (accessed on 5 January 2020)

Nahui, Z., Bojie, F., Yihe, L., and Shuai, W. (2014). Poverty Reduction, Environmental Protection and Ecosystem Services: A Prospective Theory for Sustainable Development. Chin. Geogra. Sci, vol. 24(1), p. 83-92.

Peng, J., Tian, L., Liu, Y., Zhao, M., Hu, $\mathrm{Y}$ and $\mathrm{Wu}, \mathrm{J}$. (2017). Ecosystem services response to urbanization in metropolitan areas: Thresholds identification. Science of the Total Environment, vol.607-608, p.706714.

Pedro, A.A. \& Queiroz, A.F. (2019). Slum: Comparing Manucipal and census basemaps. Habitat International, vol. 83, p. 30-40.

Patterson, J.J.,Thaler, T., Hoffmann, M., Hughes, S., Oels, A., Chu, E., Mert, A., Huitema, D., Burch, S., Jordan, A. (2018). Political feasibility of $1.5^{\circ} \mathrm{C}$ societal transformations: the role of social justice. Current Opinion in Environmental Sustainability, vol.31, p.1-9.

Patra, S., Sahoo, S., Mishra, P., Mahapatra, S.C. (2018). Impacts of urbanization on land use/cover changes and its probable implications on local climate and groundwater level. Journal of 
Urban Management, vol.7(2), p.7084.

Surya, B., Syafri, S., Sahban, H and Sakti, H.H. (2020). Natural Resource Conservation Based on Community Economic Empowerment: Perspectives on Watershed Management and Slum Settlements in Makassar City, South Sulawesi, Indonesia. Land, vol. 9(4), p. 104.

Sugiyono. (2016). Research and Development Methods. For Fields: Education, Management, Social and Engineering. Penerbit. Alfabeta. Bandung.

Sadorsky, P. (2014). The effect of urbanization and industrialization on energy use in emerging economies: Implications for sustainable development. American Journal of Economics and Sociology, vol.73(2), p. 392-409.

Saefullah, A.D. (1993). Qualitative and Quantitative Approaches to the Field: Especially in Population Studies. Penerbit Media Bandung.

Sintusigha dan Mirgholami. (2013). Parallel modernization and selfcolonization: Urban evolution and practices in Bangkok and Tehran. Cities, vol. 30, p. 122-132.

Surya, B. (2015). Spatial Articulation and Co-Existence of Mode of Production in the Dynamics of Development at the Urban Fringe of Makassar City. Journal of Engineering and Applied Science, vol.10(8), p. 214-222.

Sui, D.Z and Zeng, H. (2001). Modeling the dynamics of landscape structure in Asia's emerging desa kota regions: a case study in Shenzhen. Landscape and Urban Planning, vol. 53, p. 37-52.

Surya, B., Ahmad, D.N.A., Sakti, H.H and Hernita Sahban. Land Use Change, Spatial Interaction, and Sustainable Development in the
Metropolitan Urban Areas, South Sulawesi Province, Indonesia. Land, vol.9(3), p. 95.

Surya, B. (2016). The Processes Analysis of Urbanization, Spatial Articulation, Social Change and Social Capital Difference in the Dynamics of New Town Development in the Fringe Area of Makassar City (Case Study: In Metro Tanjung Bunga Area, Makassar City. Procedia-Social and Behavioral Sciences, vol. 227. 216231.

Surya, B. (2016). Change Phenomena of Spatial Physical in the Dynamics of Development in Urban Fringe Area. Indonesian Journal of Geography, vol.48 (2), p.118-134.

Surya, B., Saleh, H., Remmang, H. (2018). Economic Gentrification and Socio - Cultural Transformation Metropolitan Suburban of Mamminasata. Journal of Engineering and Applied Science, vol. 13 (15), p.6072-6084.

Surya, B., Saleh H., Ariyanto. (2018b). Transformation of metropolitan suburban area (a study on new town development in MoncongloePattalassang Metropolitan Maminasata). IOP Conference. Series: Earth and Environmental Science, vol.202.012027, p.1-10.

Surya, B, Ruslan, M., Abubakar, H. (2018). Inequility of Space Reproduction Control and Urban Slum Area Management Sustainability (Case Study: Slum Area of Buloa Urban Village in Makassar City). Journal of Engineering and Applied Science, vol.13 (15), p.6033-6042.

Surya, B. (2015). Spatial Interaction Pattern and the Process of City Activity Formation System (Case study, Ternate City, Tidore Archipelago City and Sofifi City of 
North Maluku, Indonesia)". Research Journal of Applied Sciences, vol. 10(12), p. 880-892.

Surya, B. (2015c). Optimization of Function and Role of Traditional Markets in Urban Development System of Ketapang City (A Case Study: Range Sentap Market, Delta Pawan Subdistrict, Ketapang City). World Applied Sciences Journal, vol. 33(9), p.1457-1471.

Saleh, H., Surya, B., Hamsina, H. (2020). Implementation of Sustainable Development Goals to Makassar Zero Waste and Energy Source. International Journal of Energy Economics and Policy, vol.10(4), p. 530-538.

Timberlake, M., Wei, Y.D., Ma, X., Hao, J. (2014). Global cities with Chinese characteristics. Cities, vol. 41. Part B, p.162-170.

Todaro, P.M and Smith, C.S. (2011). Economic Development: Eleventh Edition Volume 1. Penerbit Erlangga.

Takeuchi, A., Cropper, M., Bento, A. (2008). Measuring the welfare effects of slum improvement programs: The case of Mumbai. Journal of Urban Economics, vol.64(1), 65-84.

Uddin, N. (2018). Assessing urban sustainability of slum settlements in Bangladesh: Evidence from Chittagong city. Journal of Urban Management, vol.7 (1), p. 32-42.

Vokoun, M. Amacher, G.S., Wear, D.N (2006). Scale of harvesting by nonindustrial private forest landowners. Journal of Forest Economics, vol. 11(4), p. 223-244.

Wilonoyudho, S., Rijanta, R., Keban, Y.T., Setiawan, B. (2017). Urbanization and Regional Imbalances in Indonesia. Indonesian Journal of Geography, vol. 49(2), p. 125-132.
Wu, Q., Cheng, J.,Chen, G.,Hammel, D.J.,Wu，X. (2014). Socio-spatial differentiation and residential segregation in the Chinese city based on the 2000 community-level census data: A case study of the inner city of Nanjing. Cities, vol. 39, p. 109-119.

Wang.L. (2014). Forging growth by governing the market in reform-era urban China. Cities, vol 41. Part B, p.187-193.

Wang, H., Qin, J., Zhao, B., Chen, J., Dong, L and Hu, Y. (2017). Spatio temporal dynamics of plant diversity in response to farmers' evolved settlements in Shanghai. Urban Forestry \& Urban Greening, vol. 22. P. 64-73.

Wilson, Sigismond A and Wilson, Cyril O. (2016). Land Use/Land Cover Planning Nexus: a Space-Time Multi-Scalar Assessment of Urban Growth in the Tulsa Metropolitan Statistical Area. Human Ecology. 44. 731-750. Available online: https://link.springer.com.ezproxy.ug m.ac.id/article/10.1007/s10745-0169857-2. (Accessed on 6 Maret 2020)

Ye, C., Chen, M., Duan, J., Yang, D. (2017). Uneven development, urbanization, and production of space in the middle-scale region based on the case of Jiangsu province, China. Habitat International, vol.66, p.106-116.

Ye, C., Chen, M., Chen, R., Guo, Z. (2014). Multi-scalar separations: Land use and production of space in Xianlin, a university town in Nanjing, China. Habitat International, vol. 42, p. 264-272.

Zhang, S. (2014). Land-centered urban politics in transitional China - Can they be explained by Growth 
Machine Theory? Cities, vol. 41. Part B, p. 179-186.

Zhang, C., Lu, B., Song, Y. (2012). Involving the Community in Inner City Renewal: A Case Study of Nanluogu in Beijing. Journal of Urban Management, vol.1(2), p. 5371. 